DOI https://doi.org/10.30525/978-9934-26-111-4-56

\title{
ВИВЧЕННЯ КОЛЬОРОВИХ ПШЕНИЦЬ ДЛЯ СТВОРЕННЯ СОРТІВ ХАРЧОВОГО НАПРЯМУ ВИКОРИСТАННЯ
}

\author{
Усова 3. В. \\ кандидат сільськогосподарських наук, старший науковий співробітник, \\ провідний науковий співробітник лабораторї селекиії \\ та фізіологї пшениці \\ Інститут рослинництва імені В. Я. Юр єва Національної академї \\ аграрних наук Украӥни \\ Леонов О. Ю. \\ доктор сільськогосподарських наук, стариий науковий співробітник, \\ завідувач лабораторії селекиії та фізіологї пшениці \\ Інститут рослинництва імені В. Я. Юр 'єва \\ Національної академї аграрних наук Украӥни
}

\section{Суворова К. Ю.}

кандидат біологічних наук, стариий науковий співробітник лабораторії селекиї

та фізіологї пшеницуі

Інститут рослинництва імені В. Я. Юр 'єва

Національної академї аграрних наук України

м. Харків, Україна

У структурі харчування сучасної людини використовується безліч природних i штучних харчових продуктів. Але в останні роки в це харчове різноманіття все більш впевнено входять функціональні продукти (ФП) - Food for Specific Health Use. Відмінністю цих продуктів від традиційних $є$ те, що вони не тільки характеризуються певними поживними властивостями а й мають цілеспрямовану дію на функціональну активність окремих органів, систем i організму в цілому, стимулюють їх працездатність з конкретною профілактичною та лікувально-оздоровчою метою. Однією з відмінностей ФП від біологічно активних добавок $є$ те, що вони містять корисний інгредієнт безпосередньо в складі традиційного харчового продукту $i$ в фізіологічної концентрації [1, с. 24-27].

Науковці у всьому світі активно працюють в аспекті біофортифікації над так званим «забарвленим» або пігментованим зерном 
ячменю, пшениці, рису з метою підвищення його біологічної цінності та створення 3 них продуктів функціонального (оздоровчого) харчування [2, с. 95-127; 3, с. 207-240].

Крім сортів пшениці з червоним зерном світова селекція створює численні сорти з білим, чорним і блакитним зерном [4, с. 90-94]. Білозерні сорти пшениці поширені в США, Австралії, Канаді, Китаї. Чорнозерні сорти пшениці особливо ціняться в Китаї, де в результаті численних фундаментальних наукових досліджень доведено надзвичайно високу біологічну цінність такого зерна [5, с. 8533-8536].

Сорти із чорним і з блакитним зерном містять цілий комплекс речовин (дельфінін-3-глюкозид, дельфінін-3-рутинозид, ціанідин-3глюкозид, 3-ціанідин рутинозид) із високою антиоксидантною активністю, яку сучасна нутриціологія розцінює як головний харчовий чинник антиракової профілактики, протизапальної дії, профілактики оксидативного стресу, цукрового діабету, хвороб очей [6, с. 113-120; 7, с. 989-996].

Генетичний контроль незвичайної для пшениці пігментації зерна достеменно досліджений, відомі також джерела іiі походження $[8$, c. 74-79].

В Інституті рослинництва імені В.Я. Юр'єва НААН роботу зі створення селекційного матеріалу для сортів пшениці харчового напряму використання зерна почали із скрінінгу колекційних зразків Національного центру генетичних ресурсів росин України. До вивчення були залучені: 5 зразків 3 блакитним зерном, 3 - 3 фіолетовим, 2 - 3 білим, а також червонозерні сорти, які вирощуються в Україні. В дослідженнях використані зразки з України, Росії, Словаччини, Швейцарії, Угорщини, Литви, Австрії, Румунії.

За результатами лабораторних досліджень виділено зразки, які мали високу загальну антиоксидантну здатність(АОА) (ехгк (еквівалент хлорогенової кислоти) >650 мкг/г) блакитнозерні: KM 186/2 (SVK), Scorpion (AUS), Виридиферругинеум 2022-87 (RUS), Гермакианум 2005-87 (RUS), зразок з фіолетовим зерном Blue $\times$ Red (SVK) $-54,35 \%$ (ехгк 794,1 мкг/г). За вмістом мікроелементів високі значення мали блакитно- та білозернізерні зразки: Zn (Гермакианум 2005-87 -33, 145 мкг/г), Fe (Виридиферругинеум 2022-87 - 48,885 мкг/г), Cu (Білява - 4,045 мкг/г). Рівень антиоксидантної активності спиртових екстрактів борошна і шроту пшениці визначали на основі їх властивості нейтралізувати стабільні вільні радикали розчину 2,2-дифеніл-1пірилгідразил (DPPH).

Загальний вміст фенолів визначали в шроті за методом ФолінаЧокальтеу [9, с. 128-139]. У дослідженій виборці вміст фенольних сполук коливався в межах від 591,5 мкг/г еквівалент галової кислоти до 242 
948,5 мкг/г еквівалент галової кислоти. Високим вмістом фенолів в зерні (>900 мкг/г) характеризувались 2 зразки з червоним зерном MV Nador (HUN), Kурс (RUS), самий високий вміст фенолів визначено у червонозерного сорту Южанка (RUS). Низьким вмістом фенолів в зерні $(<700$ мкг/г) характеризувались 3 зразки з червоним зерном: Симпатія (UKR), Nikifor (RUM), Viglanka (SVK), мінімальний вміст фенольних сполук було встановлено у білозерного сорту Білява (UKR), що може бути пов'язано 3 відсутністю антоціанидів та проантоціанидів в оболонках зерна цього сорту.

За результатами польових досліджень 2017-2019 рр. колекційні зразки 3 кольоровим зерном істотно поступалися за показником урожайності червонозерним сортам. Для блакитнозерних зразків вона складала 3,6-6,9 т/га, фіолетовозерних - 4,6-6,5 т/га, червонозерних 6,4-9,3 т/га. Також відмічено, що сорти 3 високою АОА виколошувались на 2-5 діб пізніше за червонозерні сорти, суттєвих різниць за стійкістю до листкових хвороб не спостерігалось.

В результаті проведених досліджень виділені джерела 3 різним кольором зерна, які активно використовуються у селекційній роботі 3 метою створення сортів харчового напряму використання для здорового (функціонального) харчування. За їх участі створено селекційні лінії, які проходять вивчення у різних селекційних розсадниках.

\section{Література:}

1. Селиванская И.А. Современное питание и функциональные продукты. Зернові продукти і комбікорми. 2014. № 3 (55). С. 24-27.

2. Рибалка О.I., Моргун В.В., Моргун Б.В. Кольорове зерно пшениці і ячменю - нова стратегія селекції зернових культур із високою біологічною цінністю зерна. Фізіологія рослин $i$ генетика. 2020. T. 52. № 2. C. 95-127. https://doi.org/10.15407/frg2020.02.095

3. Рибалка O.І., Моргун В.В., Моргун Б.В., Поліщук С.С. Генетичні основи нового напряму селекції оригінальних за якістю зерна класів пшениці (Triticum aestivum L.) і тритикале (×Triticosecale Wittmack). Фізіологія рослин $i$ генетика. 2019. Т. 51. № 3. С. 207-240. https://doi.org/10.15407/frg2019.03.207

4. Martinek P., Škorpík M., Chrpová J., Fučík P., Schweiger J. Development of the new winter wheat variety Skorpion with blue grain. Czech. J. Genet. Plant Breed. 2013. V. 49. P. 90-94.

5. Li W., Shan F., Sun Sh., Corke H. \& Beta T. Free radical scavenging properties and phenolic content of Chinese black-grained wheat. J. Agric. Food Chem. 2005. V.53 (22). P. 8533-8536.

6. Knievel D., Abdel-Aal E., Rabalski I., Nakamura T. \& Hucl P. Grain color development and the inheritance of high anthocyanin blue 
aleurone and purple pericarpin spring wheat (Triticum aestivum L.). J. Cereal Sci. 2009. V. 50. P. 113-120.

7. Lamy S., Blanchette M., Michaud-Levesque J., Lafleur R., Durocher Y., Moghrabi A., Barrette S., Gingras D. \& Beliveau R. Delphinidin, a dietary anthocyanidin, inhibits vascular endothelial growth factor receptor-2 phosphorylation. Carcinogenesis. 2006. № 27. P. 989-996.

8. Nandy S., Chen Q., Sun Sh., Ahmad F., Graf R. \& Kereliuk G. Nutritional analyses and their inheritance properties in colored wheat seed lines from different origins using near-infrared spectroscopy. Amer. J. Plant. Sci. Biotechnol. 2008. 2(2). P. 74-79.

9. Ермаков А.И. Методы биохимического исследования растений. М.: Колос, 1982. С. 128-139

DOI https://doi.org/10.30525/978-9934-26-111-4-57

\title{
ЗНАЧЕННЯ МІКРОБНИХ ПРЕПАРАТІВ У РОЗВИТКУ СТАЛОГО СІЛЬСЬКОГО ГОСПОДАРСТВА
}

\author{
Шевченко Л. А. \\ кандидат сільськогосподарських наук, \\ доцент кафедри аграних технологій та лісового господарства \\ Національний університет «Чернігівська політехніка» \\ Рябуха Г. I. \\ кандидат економічних наук, \\ дочент кафедри туризму \\ Національний університет «Чернісівська політехніка» \\ Бондар I. М. \\ старший викладач кафедри аграних технологій та лісового \\ господарства \\ Національний університет «Чернігівська політехніка» \\ м. Чернігів, Украӥна
}

\begin{abstract}
Сьогодні більшість агровиробників погодяться, що одним із сучасних i важливих агротехнічних заходів для підвищення продуктивності сільськогосподарських культур $€$ застосування мікробних препаратів створених на основі грунтових мікроорганізмів, що стимулюють ріст і розвиток рослин. Серед переваг даних
\end{abstract}

